\title{
KESETARAAN HAK WARGA BINAAN DI LEMBAGA PEMASYARAKATAN KELAS II A DAN B YOGYAKARTA
}

\author{
Siti Nurningsih dan Nur Hidayah \\ Pendidikan Sosiologi Universitas Negeri Yogyakarta \\ Email: sitinurningsih0@gmailcom
}

\begin{abstract}
Abstrak
Penelitian ini bertujuan untuk mendeskripsikan kesetaraan hak warga binaan laki-laki dan perempuan, serta mengetahui faktor pendorong dan penghambat pelaksanaan program kemandirian di Lembaga Pemasyarakatan Wirogunan Kelas II A dan B Yogyakarta. Metode yang digunakan dalam penelitian ini adalah kualitatif deskriptif. Informan dalam penelitian ini berjumlah 10 orang yang dipilih dengan menggunakan teknik purposive sampling. Teknik pengumpulan data dalam penelitian ini menggunakan wawancara, observasi, dan dokumentasi. Teknik validitas data menggunakan trianggulasi sumber. Teknik analisa data menggunakan analisis model interaktif Miles dan Huberman. Hasil dari penelitian ini menunjukkan bahwa adanya kesetaraan hak antara warga binaan laki-laki dan perempuan di lembaga pemasyarakatan kelas II A dan B. Hal tersebut, terlihat dari adanya kesetaraan gender pada aspek akses, partisipasi, kontrol dan manfaat. Pelaksanaan program-program kemandirian memiliki faktor pendorong dan penghambat yang memengaruhi sukses tidaknya program tersebut. Sejak diterapkan program kemandirian tersebut telah terjadi adanya kesetaraan gender antara hak warga binaan laki-laki dan perempuan.
\end{abstract}

Kata Kunci: Kesetaraan Gender, Warga Binaan Pemasyarakat (WBP), Program Kemandirian

This study aims to describe the equal rights of male and female assisted citizens, and to determine the driving and inhibiting factors for the implementation of the independence program at Wirogunan Prison Class II A and B Yogyakarta. The method used in this research is qualitative. There are 10 informants in this study who were selected using purposive sampling technique. The data analysis technique used interactive model analysis by Miles and Huberman. The results of this study indicate that there is equal rights between men and women in prisons Class II $A$ and $B$. This can be seen from the existence of gender equality in the aspects of access, participation, control and benefits. The implementation of self-reliance programs has driving and inhibiting factors that influence the success or failure of the program. Since the implementation of the independence program, there has been gender equality between the rights of male and female assisted citizens.

Keywords: Gender Equality, Community Assisted People (WBP), Independence Program

\section{Pendahuluan}

Bangsa Indonesia memiliki kewajiban untuk mematuhi hukum yang berlaku tanpa terkecuali, dan memiliki hak asasi manusia yang telah tercantum dalam Undang-undang. Negara Indonesia memiliki kewajiban untuk melindungi warga negaranya tanpa terkecuali. Jika seseorang melakukan perlawan terhadap hukum atau penyimpangan sosial yang tidak sesuai dengan norma hukum, maka akan dipidanakan secara hukum, dan dikenakan sanksi berdasarkan keputusan hakim sesuai dengan hukum yang berlaku. 
Hakim yang mengadili pelaku perlu untuk bertindak dengan baik dan mengadili perkara untuk mencapai suatu keadilan. Begitu pun dengan kehidupan mantan warga binaan setelah kembali kemasyarakat, dikhawatirkan mereka akan mendapatkan stigma dan perilaku ketidakadilan dari masyarakat. Ketidakadilan sering menimpa warga binaan atau mantan warga binaan ketika hidup di lingkungan masyarakat, seperti dikucilkan atau tidak dianggap bagian dari keluarga mereka sendiri, dan tidak diizinkan bekerja di salah satu tempat. Hal kecil tersebut merupakan salah satu bentuk suatu ketidakadilan. Mereka ingin mendapatkan keadilan dan kesejahteraan dilingkungan lapas, lingkungan keluarga, dan lingkungan masyarakat.

Warga binaan yang direnggut kebebasannya oleh negara atas dasar hukum, merupakan kelompok yang rentan dalam masyarakat. Kemungkinan mereka untuk mendapatkan perlakukan baik dan tanggapan baik dari masyarakat masih sulit, bahkan ada masyarakat yang masih belum bisa menerima keberadaan mereka setelah terkena kasus dan dianggap sebagai warga binaan atau mantan warga binaan. Sehingga perlu memberikan pemahaman kepada masyarakat untuk dapat menerima keberadaan mereka sebagai warga binaan atau mantan warga binaan, baik pelaku lakilaki maupun perempuan.

Berdasarkan Sistem Database Pemasyarakatan oleh Kanwil Yogyakarta pada Januari 2019, bahwa jumlah tahanan perempuan sebanyak 38 orang, dan jumlah narapidana perempuan sebanyak 84 orang dengan kasus penipuan, korupsi, pencurian, narkotika, dan sebagainya. Tindakan kriminal dan modus-modus tindakan kejahatan yang dilakukan mengikuti perkembangan zamannya, seiring dengan perkembangan zaman seperti perkembangan pada teknologi, yang kemudian dapat memengaruhi pola pikir dan perbuatan manusia. Pelanggaran kasus-kasus hukum sering dilakukan oleh laki-laki dari kalangan muda hingga kalangan tua. Akan tetapi, perempuan juga berpotensi untuk melakukan tindakan kriminal atau tindakan kejahatan. Tindakan yang dilakukan biasanya disebabkan karena faktor ekonomi dan faktor sosial, Sujarwa, Polemik Gender: 104 (dalam Yunitri Sumarauw, halaman 4). Menurut Badan Pusat Statistik, dari tahun 2011-2013 terdapat 342.084 kasus kejahatan di Indonesia yang telah dilaporkan oleh Polda Metro Jaya. Tindakan kriminal bukan hanya dilakukan oleh laki-laki melainkan juga dilakukan oleh perempuan. Tindakan kriminal yang dilakukan oleh perempuan seperti narkoba, pencurian, penipuan, korupsi, dan perbuatan yang melanggar hukum lainnya (Afriyanti, 2013:18). Berdasarkan Sistem Database Pemasyarakatan oleh Kanwil pada Januari 2019, bahwa jumlah tahanan perempuan sebanyak 38 orang, dan jumlah narapidana perempuan sebanyak 84 orang dengan 
kasus penipuan, korupsi, pencurian, narkotika, dan sebagainya.

Peran lembaga pemasyarakatan membentuk warga binaan menjadi orang yang lebih baik dan memperbaiki kesalahan, dan memberikan binaan, serta pengetahuan. Istilah "pemasyarakatan" merupakan istilah yang lazim digunakan untuk memperhalus kata, yang semula "penjara" berubah menjadi "pemasyarakatan". Warga binaan yang direnggut kekebasannya oleh negara berdasarkan hukum, mereka sangat rentan di masyarakat. Kemungkinan mereka menerima risiko diperlakukan buruk, diinterogasi dengan menggunakan kekerasan untuk memeroleh pengakuan, disiksa, penghilangan secara paksa, hingga kepada menerima kondisi tempat tahanan yang tidak manusiawi dan merendahkan martabat manusia, sangat mudah menimpa warga binaan.

Berdasarkan Sistem Database Pemasyarakatan oleh Kanwil pada Januari 2019, bahwa Lembaga Pemasyarakatan yang ada di Indonesia melebihi kapasitas. Terdapat tiga provinsi di Indonesia yang kapasitasnya masih rendah, yaitu D.I. Yogyakarta over kapasitas 0\%, Maluku over kapasitas 0\%, dan Maluku Utara 0\%. Menurut Direktur Jenderal Lembaga Pemasyarakatan (Lapas) Kementerian Hukum dan HAM I Wayan Kusnianta Dusak, "Idealnya kami memerlukan 1.000 lapas, tapi sekarang baru ada 512 lapas." (Tempo.co, 17 Mei 2017).
Sesuai dengan tujuan dan tugas lapas yang memberikan pelayanan dalam kesetaraan hak warga binaan, lapas selalu berpedoman pada undang-undang yang berlaku. Penelitian ini dilakukan sebagai kajian tentang Kesetaraan Hak Warga Binaan Laki-Laki dan Perempuan di Lembaga Pemasyarakatan Kelas II A dan Kelas II B di Yogyakarta. Kesetaraan gender yang ada di Indonesia sudah menempatkan wanita secara baik dan tidak tejadi diskriminasi antara kaum laki-laki dan perempuan. Perempuan sudah selalu dilibatkan dalam proses pembangunan, dan memberikan partisipasi atau suara. Perempuan diberikan kebebasan sepenuhnya untuk mengeksplor kemampuan mereka. Begitu pun dengan kesetaraan gender yang ada di lapas Kelas II A dan Kelas II B ini telah berjalan semestinya, dan memberikan hak-hak sesuai dengan undang-undang yang berlaku. Khususnya kepada warga binaan perempuan dilibatkan dalam memberikan hak berpolitik dan pendidikan seperti pendidikan Paket $\mathrm{C}$, kerohanian, dan keterampilan. Sarana dan prasarana di lapas telah mendukung untuk terwujudnya kesetaraan geder, seperti poli klinik/puskesmas, koperasi, transportasi, hak untuk makan sekaligus pemenuhan kebutuhan lainnya.

\section{Metode}

Penelitian ini menggunakan metode penelitian kualitatif dengan pendekatan 
kualitatif deskriptif. Lokasi penelitian ini dilakukan di Lembaga Pemasyarakatan Kelas II A dan Lembaga Pemasyarakatan Kelas II B Yogyakarta Jalan Taman Siswa No.6 Yogyakarta 55111. Alasan peneliti memilih lokasi penelitian di lapas tersebut karena Lembaga Pemasyarakatan tersebut telah melakukan kesetaraan gender dengan berbagai layanan atau program yang diberikan oleh pihak lapas. Selain itu, peneliti telah melihat bagaimana layanan dan hak yang diberikan kepada warga binaan untuk mewujudkan kesetaraan hak warga binaan. Penelitian ini dilakukan selama 3 bulan terhitung dari bulan April 2019 sampai bulan Juni 2019. Subjek penelitian ini menggunakan teknik purposive sampling, yaitu: warga binaan laki-laki dan perempuan, dan petugas lapas laki-laki dan perempuan. Teknik pengumpulan data menggunakan obsrvasi, wawancara, dan dokumentasi.

\section{Hasil dan Pembahasan}

Di Indonesia mengenal istilah "pemasyarakatan" yang merupakan pembinaan untuk Warga Binaan Pemasyarakatan (WBP). Menurut UU No.12 Tahun 1995 Pasal 1 Ayat 2 tentang pemasyarakatan bahwa, "sistem pemasyarakatan adalah suatu tatanan mengenai arah dan batas serta cara pembinaan Warga Binaan Pemasyarakatan berdasarkan Pancasila yang dilaksanakan secara terpadu antara pembina, yang dibina, dan masyarakat untuk meningkatkan kualitas Warga Binaan Pemasyarakatan agar menyadari kesalahan, memperbaiki diri, dan tidak mengulangi tindak pidana sehingga dapat diterima kembali oleh lingkungan masyarakat, dapat aktif berperan dalam pembangunan, dan dapat hidup secara wajar sebagai warga yang baik dan bertanggung jawab". Sesuai dengan Pasal 1 Ayat 3, bahwa "Lembaga Pemasyarakatan yang selanjutnya disebut LAPAS adalah tempat untuk melaksanakan pembinaan Narapidana dan Anak Didik Pemasyarakatan. Fungsi sistem pemasyarakatan telah tercantum dalam Pasal 3, bahwa "sistem pemasyarakatan berfungsi menyiapkan Warga Binaan Pemasyarakatan agar dapat berintegrasi secara sehat dengan masyarakat, sehingga dapat berperan kembali sebagai anggota masyarakat yang bebas dan bertanggung jawab".

Praktik sistem pemasyarakatan bukan hanya melibatkan para petugas dari pihak Lembaga Pemasyarakatan, melainkan juga melibatkan keluarga dan masyarakat untuk berpartisipasi dalam "memasyarakatkan" mereka seperti manusia normal pada umumnya setelah mereka keluar dari rutan. Setidaknya mereka tetap mendapatkan perlakuan baik, dibina dan dibimbing ke arah yang lebih baik, serta tidak dikucilkan oleh keluarga dan masyarakat.

Lembaga pemasyarakatan memberikan warga binaan programprogram kemandirian, dengan tujuan agar warga binaan dapat mandiri dan diterima 
masyarakat luar setelah habis masa hukumannya. Program kemandirian diberikan sebagai bekal dan pengetahuan untuk warga binaan, serta sebagai kegiatan keterampilan sehari-hari di lapas. Programprogram tersebut biasa disebut dengan bimker (bimbingan kerja). Bimbingan kerja yang ada di Lembaga Pemasyarakatan Kalas II A dan Kelas II B berbeda, disesuaikan dengan kebutuhan warga binaan laki-laki dan perempuan.

Lembaga Pemasyarakatan Kelas II A Yogyakarta memiliki bimker yang digunakan sebagai tempat untuk warga binaan mendapatkan pengetahuan, bimbingan, bekerja, dan menuangkan inspirasinya dalam sebuah karya. Adapun bimker yang ada di lapas tersebut seperti musik, produksi minuman susu kedelai, bengkel mobil dan motor (otomotif), laundry, pertukangan, perkebunan, produksi tas kado, produksi sepatu kulit, souvenir dari sisa-sisa bahan produksi, dan melukis.

Lembaga Pemasyarakatan Perempuan Kelas II B Yogyakarta memiliki bimker yang digunakan sebagai tempat untuk warga binaan mendapatkan pengetahuan, bimbingan, bekerja, dan keterampilan. Adapun bimker yang ada di lapas tersebut seperti musik akustik dan hadroh, keterampilan salon, merajut, tas manik-manik, handycraft, catering, pembuatan aksesoris, menjahit, souvenir, dan hiasan dinding.

Membahas terkait konsep gender, kata gender dalam kamus bahasa Inggris

adalah jenis kelamin, seks. Menurut The Contemporary

English-Indoneisan

Dictonary, gender adalah penggolongan jenis kelamin. Menurut Cixous dalam Tong (2004:41), gender diartikan sebagai perbedaan yang tampak antara laki-laki dan perempuan yang dilihat dari segi nilai dan tingkah laku. Gender merupakan perbedaan antara laki-laki dan perempuan secara kultural dan secara emosional, dan memiliki hak yang sama.

Kesetaraan gender merupakan persamaan kondisi antara laki-laki dan perempuan dalam memperoleh haknya sebagai manusia dan dapat berperan serta berpartisipasi dalam kegiatan yang dapat membangun dan berkembang seperti pendidikan, politik, sosial budaya, ekonomi, hukum, nilai, norma, dan sebagainya. Adapun terwujudnya kesetaraan gender memiliki 4 indikator, yaitu: akses, partisipasi, kontrol, dan manfaat. Akses merupakan kesempatan dalam memperoleh suatu kebutuhan, dan memperoleh akses secara adil antara laki-laki dan perempuan, serta menggunakan sumber daya yang ada di wilayah tersebut. Partisipasi merupakan turut serta, keikutsertaan seseorang atau kelompok dalam mengikuti suatu kegiatan, dan menjalankan perannya sebagai laki-laki dan perempuan. Kontrol merupakan kuasa atau wewenang seseorang dalam mengambil suatu keputusan. Kontrol memiliki sistem, kebijakan, dan aturan yang harus dipatuhi dan menjadi kesepakatan bersama. Manfaat merupakan fungsi, 
kegunaan yang dapat dinikmati oleh seseorang atau kelompok.

Usaha yang dilakukan oleh pihak lapas dalam menunjang hak-hak warga binaan laki-laki dan perempuan adalah memberikan pelayanan dan fasilitas umum yang dapat digunakan oleh warga binaan. Pemenuhan hak warga binaan, pemberian fasilitas, dan pelayanan di lapas berpedoman pada UU RI No. 12 Tahun 1995 tentang Pemasyarakatan. Adapun hak-hak tersebut meliputi:

a. Melakukan ibadah sesuai dengan agama atau kepercayaannya

b. Mendapat perawatan, baik perawatan rohani maupun jasmani

c. Mendapatkan pendidikan dan pengajaran

d. Mendapatkan pelayanan kesehatan dan makanan yang layak

e. Menyampaikan keluhan

f. Mendapatkan bahan bacaan dan mengikuti siaran media massa lainnya yang tidak dilarang

g. Mendapatkan upah atau premi atas pekerjaan yang dilakukan

h. Menerima kunjungan keluarga, penasihat hukum, atau orang tertentu lainnya

i. Mendapatkan pengurangan masa pidana (remisi)

j. Mendapatkan kesempatan berasimilasi termasuk cuti mengunjungi keluarga

k. Mendapatkan pembebasan bersyarat

I. Mendapatkan cuti menjelang bebas, dan

m. Mendapatkan hak-hak lain sesuai dengan peraturan perundang-undangan yang berlaku.

Hak yang menjadi pembeda warga binaan laki-laki dengan perempuan adalah warga binaan perempuan mendapatkan haknya sebagai kodratnya perempuan, seperti mengalami menstruasi, mengandung, melahirkan, dan menyusui. Pemberian pembalut kepada warga binaan dan tersedianya koperasi sangat dibutuhkan warga binaan untuk memenuhi kebutuhan sehari-hari. Jika warga binaan sedang mengandung, mereka mendapatkan hak untuk melakukan cek kesehatan janin yang dibimbing petugas lapas. Kemudian, untuk warga binaan yang melakukan proses persalinan mendapatkan hak sepenuhnya sesuai dengan undangundang dengan melakukan rujukan di rumah sakit terdekat yang dibimbing petugas lapas, dan biaya sudah ditanggung oleh pemerintah. Mereka mendapatkan hak untuk menyusui dan bersama bayinya di lapas selama 2 tahun. Jika si bayi sudah berusia 2 tahun harus dibawa pulang oleh keluarga. Sedangkan untuk warga binaan laki-laki diberikan kebebasan untuk merokok di lapas, bahkan tersedia koperasi dengan menjual berbagai rokok.

Adapun wujud dalam pemenuhan hak warga binaan agar mendapatkan kesejahteraan warga binaan melalui pembinaan kepribadian dan pembinaan kemandirian. Pembinaan kepribadian bertujuan untuk meningkatkan ketakwaan 
warga binaan. Wujud dari pembinaan kepribadian pembinaan agama dengan mengadakan kelas TPA setiap pagi dan mengadakan pengajian setiap bulannya. Pembinaan kemandirian bertujuan untuk menjadikan warga binaan mandiri melalui pembekalan ilmu pengetahuan dan keterampilan. Wujud dari pembinaan kemandirian kejar paket, pendidikan olahraga, pelatihan keterampilan di bimker, seperti bengkel otomotif, souvenir, hendicraft, musik, tata boga, menjahit, salon kecantikan, perkebunan, dan lain-lain.

Secara umum, warga binaan sudah sejahtera dan hidup dengan layak di lembaga pemasyarakatan. Pemberian fasilitas yang sudah baik dan mendukung untuk pemenuhan kebutuhan warga binaan, serta pemenuhan hak warga binaanyang sudah baik, membuat warga binaan menjadi lebih baik dan memiliki pengetahuan, nilai dan moral yang baik, disiplin, serta lingkungan yang lebih agamis. Sebagai warga binaan yang hak kebebasannya telah direggut dan dinyatakan bersalah secara hukum, mereka tetap memiliki hak sebagai makhluk sosial yang dilindungi secara hukum, serta hak-haknya sebagai WNI.

Adapun yang menjadi faktor pendorong dari program kemandirian sebagai berikut:

a. Partisipasi dan antusias warga binaan dalam mengikuti kegiatan yang diadakan.

b. Biaya dan fasilitas yang diberikan pihak lapas dalam kegiatan bimbingan kerja. c. Pelayanan yang diberikan petugas kepada warga binaan dalam proses pembinaan seperti ramah tamahnya kepada warga binaan.

d. Pembinaan keterampilan yang dilakukan di lapas berdasarkan potensi yang dimiliki oleh warga binaan dan kebutuhan warga binaan.

e. Adanya kerja sama yang baik antara pihak lapas atau petugas lapas dengan pembina teknis dari luar lapas agar kegiatan dapat berjalan dengan baik.

f. Adanya bantuan dari warga binaan yang sudah memiliki keterampilan di salah satu bidang pembinaan dan dapat membantu pembina dalam kegiatan berlangsung.

g. Adanya subsidi dari pemerintah dan dari luar seperti lembaga-lembaga dan bekerja sama dengan pihak luar lapas yang bertujuan untuk mendukung kegiatan tersebut dalam memberikan fasilitas.

Adapun faktor penghambat dari program kemandirian sebagai berikut:

a. Keaktifan dan partisipasi warga binaan dalam kegiatan pelatihan maupun bimker.

b. Dana yang terbatas dari programprogram kemandirian.

c. Terbatasnya fasilitas yang tersedia seperti mesin jahit dalam pelaksanaan program kemandirian.

\section{Simpulan}

Lembaga Pemasyarakatan Kelas II A 
merupakan lembaga pemasyarakatan untuk warga binaan laki-laki, dan bersebelahan dengan Lembaga Pemasyarakatan Perempuan Kelas II B yang merupakan lembaga pemasyarakatan perempuan. Sistem administrasi masih menjadi satu dengan Lembaga Pemasyarakatan Kelas II A.

Secara umum, warga binaan sudah sejahtera dan hidup dengan layak di lembaga pemasyarakatan. Pemberian fasilitas yang sudah baik dan mendukung untuk pemenuhan kebutuhan warga binaan dalam aspek pengetahuan, nilai dan moral yang baik, disiplin, serta lingkungan yang lebih agamis. Sebagai warga binaan yang hak kebebasannya telah direggut dan dinyatakan bersalah secara hukum, mereka tetap memiliki hak sebagai makhluk sosial yang dilindungi secara hukum, serta hakhaknya sebagai WNI.

Pada dasarnya, kesetaraan hak warga binaan dan program-program pembinaan yang ada perlu partisipasi dari warga binaan sendiri dan petugas lapas, serta pihak luar yang bersedia turut berperan dalam pemenuhan hak-hak warga binaan dan pelaksaan program-program pembinaan di lapas. Partisipasi warga binaan dan masyarakat menjadi faktor pendukung untuk terwujudnya kesetaraan hak warga binaan dan pelaksanaan program kemandirian. Sedangkan dalam pelaksaan kegiatan tersebut, seringkali membutuhkan dana. Berkaitan dengan hal tersebut, pihak lapas bekerja sama dengan pihak luar untuk mendukung pendanaan seluruh kegiatan yang ada di lembaga pemasyarakatan. Selain itu, warga binaan perlu berpartisipasi aktif dalam setiap pelaksanaan kegiatan yang ada di lembaga pemasyarakatan, guna menunjang pemenuhan hak warga binaan dan pengembangan program kemandirian.

\section{Ucapan Terima Kasih}

Terima kasih kepada redaksi Jurnal Dimensia yang telah menerbitkan tulisan ini, dan kepada semua pihak yang telah mendukung penyelesaian penulisan artikel ini.

\section{Daftar Pustaka}

https://eprints.uny.ac.id/9812/2/BAB\%202 \%20\%2008110241024.pdf. Diakses pada 23 Desember 2019 pukul 12:10 WIB.

http://lppjogja.kemenkumham.go.id/index.p hp/profil/sejarah-pemasyarakatan.

Diakses pada 23 Juli 2019 pukul 11:58 WIB.

Mastuti, S., dan Kemal, D. (2010). Panduan Perencanaan dan Pengangguran Responsif Gender dalam Bidang Perdagangan di Provinsi Daerah Istimewa Yogyakarta. Jurnal IImu Komunkasi, 191-203.

Moleong, L. (2014). Metodologi Penelitian Kualitatif. Bandung: Remaja Rosdakarya.

Prastowo, Andi. (2012). Metode Penelitian Kualitatif dalam Perspektif Rancangan Penelitian. Yogyakarta: Ar-Ruzz Media.

Presiden Republik Indonesia, UndangUndang No. 12 Tahun 1995 tentang Pemasyarakatan.

Presiden Republik Indonesia, UndangUndang No. 32 Tahun 1999 tentang Syarat dan Tata Cara Pelaksanaan Hak Warga Binaan 
Dimensia : Jurnal Kajian Sosiologi | Vol 9 No 1 | pISSN: 1978 -192X elSSN: 2654-9344

Pemasyarakatan.

Ritzer, George dan Douglas J. Goodman. Cetakan ke 9. Teori Sosiologi Dari Teori Sosiologi Klasik Sampai Perkembangan Mutakhir Teori Sosial Postmodern. Kreasi Wacana.

Tohirin. (2013). Metode Penelitian Kualitatif dalam Pendidikan dan Bimbingan Konseling: Pendekatan Praktis untuk Peneliti Pemula dan Dilengkapi dengan Contoh Transkip Hasil Wawancara Serta Penyajian Data. Jakarta: PT RajaGrafindo Persada. 